\title{
Radosława Piwowarskiego podróże nostalgiczne. Kreowanie pamięci wspólnotowej i „realizm pamięci” w narracjach o Dolinie Dzieciństwa i Młodości
}

\author{
MARIOLA MARCZAK \\ Instytut Dziennikarstwa i Komunikacji Społecznej \\ Uniwersytet Warmińsko-Mazurski w Olsztynie
}

\begin{abstract}
Marczak Mariola, Radosława Piwowarskiego podróże nostalgiczne. Kreowanie pamięci wspólnotowej i „realizm pamięci” w narracjach o Dolinie Dzieciństwa i Młodości [Radosław Piwowarski’s nostalgic trip down the memory lane. The process of creating collective memory and „the realism of memory” in his storytelling about the Valley of Childhood and Youth]. „Images” vol. XXVIII, no. 37. Poznań 2020. Adam Mickiewicz University Press. Pp. 349-363. ISSN 1731-450X. DOI 10.14746/i.2020.37.21.

The article comprises a study of the creative work of the Polish director Radosław Piwowarski, represented by his most characteristic films. The author points out the merger of stylized realism and of the nostalgic (or to be more precise - the realism stylized by means of nostalgia) as constitutive for the film style of this film artist. As a result of film analyses, the narrative structures of Piwowarski's films appear to be memory structures, as they re-create the reality remembered by the filmmaker, who usually chooses the topos of a trip down memory lane to express his personal and subjective point of view. The film's story becomes the image of the subjective reality, since it is a product of personal memory, consciousness and imagination. Piwowarski refers to the motif of the Valley of Childhood and Youth, vivid and active in the Polish literature and cinema, as an universum closed up in the past and lost forever, which, however, is accessible through the activity of recalling. The director, by the act of re-creation of a world personally remembered, actualizes the collective memory and therefore creates a community of memory with viewers of his films. The screen image of the past reality therefore gains double reliability - as a personal confession and as a record of the past; in consequence, we achieve the esthetical category of realism of memory.
\end{abstract}

KEYwORDS: Radosław Piwowarski, trip, the nostalgic, stylized realism, memory, community, storytelling

Motyw podróży jest jednym z najstarszych toposów kulturowych, a zarazem jednym z najstarszych schematów narracyjnych, wykorzystywanych dla nadania spójności strukturalnej opowieściom zarówno przekazywanym $\mathrm{w}$ formie ustnej, jak i w różnych formach narracji obrazowych (rysowanych, malowanych czy rejestrowanych na dowolnych nośnikach, od taśmy filmowej poczynając). Wiele takich opowieści znajdziemy w Biblii (w drodze był Abraham, Jonasz, Mojżesz, Święta Rodzina, Jezus i Apostołowie). Homer opowiadał o podróżach Odysa i Eneasza. Podczas tych klasycznych, archetypowych podróży dzieją się ważne sprawy: Abraham otrzymuje obietnicę potomstwa licznego jak gwiazdy na niebie, Jonasz buntuje się przeciwko powierzonej mu przez Boga mi- sji, w drodze do Emaus uczniowie rozpoznają Jezusa jako Zmartwychwstałego, Odyseusz docenia dom, który opuścił itd., itp. Już w najstarszych kościołach chrześcijańskich pojawiały się obrazy przedstawiające św. Pawła w drodze do Damaszku. Do motywów narracyjnych najbardziej oddziałujących na wyobraźnię oraz inspirujących nowożytną kulturę europejską należy literacka podróż Dantego Alighieri przez piekło, czyściec i raj.

W naszym kręgu kulturowym skojarzenie podróży z życiem tak, by tworzyła czytelną formę znaczeniową metafory, zawdzięczamy przede wszystkim Homerowi. Pod koniec XVIII wieku, na przełomie klasycyzmu i romantyzmu, podróż w literaturze stała się „,schematem narracyjnym, którym posługiwali się 
pisarze do uchwycenia wędrówki wewnętrznej człowieka-pielgrzyma szukającego sensu własnego bytu"[1]. W tym okresie nastąpiła również zasadnicza zmiana w sposobie wykorzystania tego toposu. Obecny już wcześniej, w XVII wieku w powieści łotrzykowskiej brak logicznych powiązań między poszczególnymi scenami i wątkami, w Sternowskiej powieści sentymentalnej zyskał uzasadnienie psychologiczne. Odtąd schemat narracyjny podróży stał się powszechnie wykorzystywanym w kulturze modelem strukturalnym służącym wyrazistemu i logicznemu przedstawieniu procesu, który „prowadzi do głębszego i bardziej konsekwentnego poznania wnętrza ludzkiego"[2]. Od dawna - jak widać - kojarzono ten motyw z poznaniem; najpierw chodziło o poznawanie świata w zewnętrznym wymiarze, następnie o głębszy sens wiedzy o świecie, o poszukiwanie porządku rzeczy. Szybko jednak droga w nieznane zaczęła okazywać się drogą ku poznaniu samego siebie.

Tego rodzaju formą opracowania motywu są narracje podróżnicze prezentowane jako osobiste doświadczenia. Tak właśnie opowiada Dante o swojej podróży do piekła, czyśćca i raju. W polskiej literaturze dość żywy okazał się motyw Doliny Dzieciństwa lub Doliny Młodości, będącej autonomicznym uniwersum, w którym niejako zamknięty jest czas i przestrzeń osobistej przeszłości wspominającego narratora, do której tylko on ma dostęp. Dzięki „obiektywowi” aktywnie działającej pamięci narratora rozwija się przed czytelnikiem opowieść-wspominanie, czy - jakby powiedział Norwid - od-pominanie. Najbardziej reprezentatywnym przykładem tego typu struktury narracyjnej, re-kreującej przestrzenie dzieciństwa i młodości jako wciąż

[1] H. Voisine-Jechova, Podróż jako doświadczenie, marzenie oraz poszukiwanie sensu egzystencji w prozie 1760-1820, [w:] Dziedzictwo Odyseusza: podróż, obcość i tożsamość, identyfikacja, przestrzeń, red. M. Cieśla-Korytowska, O. Płaszczewska, Kraków 2007, s. 119.

[2] Ibidem, s. 118.

[3] T. Lubelski, Poetyka powieści i filmów Tadeusza Konwickiego, Wrocław 1984. aktywne uniwersum wspominającej pamięci, rzeczywistości przeszłej dokonanej, a jednocześnie dokonującej się nieustannie w ciągłych repetycjach, jest proza Tadeusza Konwickiego oraz jego filmowe narracje[3]. Literackie Doliny Dzieciństwa i Młodości, wyłaniające się ze wspomnień narratorów, stworzyli również zapomniany dziś Wilhelm Mach (Życie duże i małe, Góry nad Morzem Czarnym) oraz Czesław Miłosz (Dolina Issy) - wymieniam najbardziej - moim zdaniem - reprezentatywne przykłady. Kanonicznym dziełem pozostaje jednak niezmiennie Pan Tadeusz Adama Mickiewicza jako żywa, nasycona emocjami wizualizacja kraju lat dziecinnych, który został na zawsze utracony. Jego artystyczny zapis, utożsamiany $\mathrm{z}$ obrazem imaginatywnym oraz ze zbiorowymi, a także indywidualnymi obrazami pamięci, w polskim kodzie kulturowym stał się synonimem wartości narodowych, jak również polskiej tożsamości zbiorowej: narodowej, kulturowej, obywatelskiej. Fenomen tego utworu w dużej mierze zasadza się na tym, że pozostając zobiektywizowaną wartością artystyczną, nie traci on nic $\mathrm{z}$ charakteru osobistego, nasyconego uczuciami świadectwa, wyrazu nostalgii za utraconą nie tylko dużą, ale także małą ojczyzną, jako miejscem zadomowienia. U Mickiewicza realizm, nostalgiczność i poetyckość łączą się w harmonijny konsonans.

W kinie rama narracyjna wspomnieniowej opowieści funkcjonuje jako najczęściej stosowana technika wprowadzania subiektywnej narracji. Doliny Dzieciństwa i Młodości są kreowane w tego typu opowieściach przez filmowców adaptujących zwykle literackie pierwowzory, jak Tadeusz Konwicki, który specyficznie filmowymi środkami wizualnie re-kreuje stworzony przez samego siebie literacki świat osobistej przeszłości, wciąż wspominanej (Zaduszki, 1961, Jak daleko stąd, jak blisko, 1971), ale także wykorzystuje cudzy tekst, by odtwarzać należący do przeszłości świat przez siebie zapamiętany (filmowa Dolina Issy, 1982, adaptacja powieści Czesława Miłosza). Dolinę Młodości na podstawie tekstu Konwickiego ukazał Andrzej Wajda, adaptując Kronikę wypadków 
miłosnych (1985). Oryginalną filmową Dolinę Dzieciństwa, łącznie z tego rodzaju topografią, stworzył Leszek Wosiewicz w Kronikach domowych (1997) oraz Dorota Kędzierzawska w filmie Diabły, diabły (1991), a także Jan Jakub Kolski w Historii kina $w$ Popielawach (1998), Wojciech Marczewski w Weiserze (200o), adaptacji powieści Pawła Huelle Weiser Dawidek. Można powiedzieć, że w pewnym sensie także Agnieszka Holland rozpoczęła swoją karierę od obrazu Doliny Młodości w Wieczorze u Abdona (1975). Po Konwickim do zbiorowej wyobraźni (tym razem pokolenia stanu wojennego, do którego należy również pisząca te słowa) trafił szczególnie mocno Andrzej Barański swoim nostalgicznym obrazem Nad rzeka, której nie ma (1991), którego tytuł adekwatnie określa istotę imaginatywnej przestrzeni wspomnień z okresu młodości/młodzieńczości.

Filmowe Doliny Dzieciństwa lub Młodości są miejscem wyraźnie wyodrębnionym topograficznie i na zawsze utraconym, gdyż należą do przeszłości. Mimo to, a może dzięki temu pozostają miejscem bezpiecznego zadomowienia, które odznacza się względną stałością, gwarantowaną przez istniejący w nim swoisty ład, utrzymywany dzięki czytelnym zasadom, nawet jeśli przetaczały się przez nie historyczne burze, które demolowały świat dorosłych. Są jednocześnie uniwersum, w którym mają miejsce różnego typu inicjacje, przede wszystkim poznawcza i erotyczna. W Dolinie Młodości dokonuje się przejście bohaterów od stanu bezpieczeństwa wynikającego z zależności od dorosłych oraz od reprezentowanego przez nich systemu społeczno-politycznego, a także dominującego wzorca kulturowego do „wybijania się na niezależność”. Wolność, której tak pragną młodzi, rozumiana przez nich jako zrywanie wszelkich więzów i ograniczeń, wiąże się jednak z pogłębianiem samoświadomości i ryzykiem odkrywania nieznanego, a to skutkuje utratą poczucia bezpieczeństwa. Wolność do...[4] okazuje się ciężarem, który bywa niebezpieczny. Droga do dojrzałości, rozumiana jako uzyskiwanie osobowej i społecznej autonomii oraz niewielkiej choćby samodzielności, oznacza symboliczne porzucenie bezpiecznej doliny i konieczność stawiania czoła niepewności, co jest charakterystyczne dla rytuałów inicjacyjnych.

„Podróżuje się, aby poznać najgłębszą prawdę o sobie [...]. Święty Augustyn miał rację, twierdząc, że nie na zawsze wypełnionym gwarem rynku, lecz we wnętrzu każdej jednostki ukryte jest wszystko to, co najistotniejsze, tam też należy się wyprawiać, by poznać prawdę"[5] - pisał niezapomniany antropolog literatury Piotr Kowalski. Podróże w głąb własnej oraz zbiorowej przeszłości są domeną Radosława Piwowarskiego, reżysera utożsamianego $\mathrm{z}$ kinem popularnym, a więc $\mathrm{z}$ definicji nienastawionym na refleksję. Zastanawiający w tym kontekście jest fakt, że Piwowarski rzadko stosuje narracyjną ramę wspomnieniową (pojawia się ona $\mathrm{w}$ Yesterday). Jest to - moim zdaniem - trop wskazujący na wspólnotę wspominania, a przynajmniej próbę stworzenia takiej wspólnoty na bazie podobnego typu przeżywania własnej przeszłości wraz ze swoimi widzami. Dzięki podobieństwu wspomnień obraz rozsnuwany za sprawą filmowej narracji ukazuje przeszłość postrzeganą jako znajoma przez wielu odbiorców. W ten sposób staje się on narzędziem tworzenia wspólnotowej pamięci - mikrocząstką, z której tworzy się pamięć zbiorowości o szerszym zakresie[6]. Dzieje się tak dlatego, że obrazy w filmach Piwowarskiego „materializują to, co jednostkowe i uogólniają to, co wspólnotowe"[7].

[4] Pojęcie to stosuję zgodnie z klasyczną wykładnią Ericha Fromma, Ucieczka od wolności, Warszawa 1997.

[5] P. Kowalski, Odyseje nasze byle jakie. Droga, przestrzeń i podróżowanie w kulturze współczesnej, Wrocław 2002, s. 133.

[6] Wobec przeszłości: pamięć przeszłości jako element kultury wspótczesnej, red. A. Szpociński, Warszawa 2005.

[7] J. Caughie, Half way to paradise, „Sight and Sound" 1992, nr 1, s. 11, cyt za: S. Radstone, Kino/ pamięć/historia, tłum. J. Jaworska, [w:] Film $i$ historia. Antologia, red. I. Kurz, Warszawa 2008, s. 349 . 
Nie zawsze film nawiązuje wprost do przeszłości twórcy, jak w Marcowych migdałach, gdzie dodatkowo powiązanie $\mathrm{z}$ realną przeszłością jest wzmacniane przez podanie w tyłówce informacji o dalszych losach pierwowzorów filmowych bohaterów. Jednak nawet gdy tak nie jest, kreacja świata przedstawionego oraz stosowane w tym celu środki narracyjne sprawiają, że widz zyskuje dostęp do nasiąkniętych nostalgią wspomnień autora, a na ekranie wyłania się świat należący zarazem do przeszłości, jak i do młodzieńczego imaginarium filmowca. Filmowa forma konserwuje rodzaj „dziecięctwa”, właściwego niektórym artystom, a dzięki niej widzowie zyskują wgląd w Dolinę Dzieciństwa i wypełniających ją marzeń o przyszłości ówczesnych młodych ludzi. Filmy Piwowarskiego zawierają, w większym lub mniejszym stopniu, elementy autobiograficzne, odtwarzają atmosferę młodości, realistycznie pokazują czas i przestrzeń zapamiętane przez reżysera i w tym sensie są sentymentalną podróżą w przeszłość, kiedy wszystko było jeszcze możliwe. „W formie moje filmy są nieco bajkowe. Lecz gdy idzie o treść, to te «bajki» zawsze biorą się z rzeczywistości" [8] - przyznaje artysta.

Ciekawe, że mimo inklinacji sentymentalnych nie ma u Piwowarskiego idealizowania przeszłości w wymiarze społecznym, tak zwanej ostalgii[9], tęsknoty za PRL-em. Ocena przeszłości historycznej tego reżysera jest trzeźwa, wyważona, a bywa nawet analityczna. Obraz rzeczywistości zapisany na ekranie jest wiarygodny poznawczo, w sensie zapisu, utrwalenia

[8] Yesterday... Wywiad z Radosławem Piwowarskim. Z Radosławem Piwowarskim rozmawia Andrzej Bukowiecki, „Magazyn Filmowy SFP" 2014, nr 36, <https://www.sfp.org.pl/ baza_wiedzy,311,20236,1,1,Yestarday-Wywiad-z-Radoslawem-Piwowarskim.html>, dostęp: 17.08.2020.

[9] D. Dabert, Ostalgia i bezpowrotność w środkowoeuropejskim kinie przełomu, „Porównania” 2012, nr 11, s. 139-155.

[10] J. Caughie, op.cit., s. 11, cyt. za: S. Radstone, op.cit., s. 350 . realiów oraz w znaczeniu dokumentowania osobistego doświadczenia, prawdy psychologicznej. Ekranowy efekt realizmu, stylizowanego za sprawą nostalgiczności, będącej pochodną mechanizmów pamięci, można zidentyfikować jako „realizm pamięci”[10].

Filmowe narracje Piwowarskiego przenoszą do Doliny Młodości jak pociąg, który uruchamia ciąg fabularnych zdarzeń w Marcowych migdałach (1989), zanim się jeszcze pojawi w podgórskiej dolinie. Metafora pociągu wjeżdżającego do leżącego w dolinie miasteczka dobrze oddaje strukturę filmowej opowieści o Dolinie Młodości, ponieważ ma ona charakter uniwersum zamkniętego, do którego prowadzi jedynie wąska droga osobistej pracy pamięci.

Prowincjonalne miasteczko, będące miejscem akcji filmu Yesterday, funkcjonuje również jako rodzaj „Doliny Dzieciństwa”. Przy czym dzieciństwo obejmuje także wczesną młodość i okres nastoletni, kiedy już nie jest się dzieckiem, a jeszcze nie jest się dorosłym, gdyż rozumiane jest ono jako okres bycia jeszcze niedojrzałym, nie w pełni ukształtowanym. Obecnie mówi się o „młodych dorosłych”, którzy jeszcze nie są w stanie funkcjonować w społeczeństwie w sposób autonomiczny z powodu braku samowystarczalności ekonomicznej. Młodzież oraz „młodzi dorośli” zależą (i zależeli w czasach młodości reżysera) jeszcze w dużej mierze od rodziców. W okresie PRL-u dodatkowo bardzo silny był element nadzoru państwa, a właściwie całego systemu społeczno-politycznego, którego najbliższym, widomym reprezentantem, pełniącym funkcję kontrolną nad życiem młodych ludzi, była szkoła. Ukryty w ramach jej struktur pedagogiczno-zarządczych aparat kontroli w postaci tajnych pracowników Służby Bezpieczeństwa również jest wyraźnie pokazywany przez Piwowarskiego (ojciec Oli oraz jego współpracownicy w Marcowych migdałach). Jest to jeden z elementów potwierdzających, że obraz rzeczywistości w jego filmach, również tych najbardziej nostalgicznych, wyraźnie inspirowanych własnym życiem, pozostaje jednocześnie realistyczny. Czasem nawet obecny jest w nich aspekt dyskursywno-anali- 
tyczny[11], dotyczący funkcjonowania młodych ludzi w opresyjnym systemie realnego socjalizmu (Marcowe migdały, 1989).

Yesterday (1984), kinowy debiut Piwowarskiego, należy do najczęściej nagradzanych utworów ekranowych tego artysty[12]. W filmie tym objawia się dominująca - moim zdaniem tendencja stylistyczna, charakterystyczna dla poetyki autorskiej Radosława Piwowarskiego - realizm i stylizacja[13], a ściślej mówiąc ich połączenie, które najlepiej charakteryzuje określenie „stylizowany realizm”. Rzeczywistość na ekranie jest bowiem rozpoznawalna przez widzów, znana z doświadczenia Polaków mieszkających w polskich miasteczkach w latach sześćdziesiątych i później, ale jest to zarazem rzeczywistość zapamiętana i wspominana. Obraz ekranowy zachowuje walor prawdziwości, mimo że jest nieco deformowany przez pamięć i nostalgiczność spojrzenia, zyskuje bowiem w zamian autentyzm osobiście przeżywanej przeszłości. Ta stylistyka przeżywania własnych wspomnień czy też wspominania z nostalgią tego, co się naprawdę wydarzyło oraz re-kreowania świata, który niegdyś istniał naprawdę, odtwarzania jego specyficznych cech, jest doskonale zapisana $\mathrm{w}$ wizualnym aspekcie oraz w sposobie kreowania narracji filmów Piwowarskiego z Yesterday i Marcowymi migdałami na czele. Reasumując, głównymi komponentami stylu reżysera są stylizowany realizm i nostalgiczność; w wypowiedziach reżysera pojawia się tego rodzaju intuicja:

Moje filmy to proste opowieści z życia ujrzanego w innym, miękkim świetle. Grzegorz Królikiewicz twierdzi, że sztuka to świat widziany przez formę. Taka definicja bardzo mi odpowiada. Dosłowność w sztuce, realizm i naturalizm - to nie dla mnie; polityka w kinie też mnie nie interesuje[14].

Realizm pamięci w opracowaniu Piwowarskiego oznacza zatem stylizowaną za sprawą filmowej formy opowieść, stworzoną na bazie życia reżysera, a czasem życia kogoś z jego bliskiego otoczenia. Potwierdza to reżyser, przedstawiając genezę swojego fabularnego debiutu: "Yesterday to z jednej strony historia z życia mojego przyjaciela Żeńki Priwieziencewa, szczęś- liwie odratowanego po tym, jak przeciął sobie żyły wskutek zawiedzionej miłości, z drugiej fragment mojej biografii: jako młody chłopak grałem na gitarze $\mathrm{w}$ zespole Poganiacze Kotów" [15].

$\mathrm{W}$ Yesterday $\mathrm{w}$ całej pełni zaprezentowane zostały wątki już znane z telewizyjnej twórczości reżysera. Film jest bowiem opowieścią o miłości i prowincji[16], pokazywanej jako margines rzeczywistości społeczno-politycznej, reprezentowanej przez środowisko młodzieży,

[11] Susannah Radstone używa terminu „dyskursywny” dla określenia swobodniejszego - wobec wymogów historycznego warsztatu - podejścia do rejestracji historii w audiowizualnej, filmowej reprodukcji - por. S. Radstone, op.cit. Piwowarski oczywiście nie uprawia kina historycznego, więc termin ten jest adekwatny, ja mam jednak na myśli także intelektualno-refleksyjne podejście do interpretacji historycznej przeszłości, które łączy się tutaj z subiektywnym obrazem przeszłości zapamiętanej.

[12] MFF w Wenecji, 1985 - nagroda FIPRESCI; MFF w San Sebastián, 1985 - za najlepszy film, dla najlepszego aktora - Piotra Siwkiewicza za rolę Ringo; Festiwal Polskich Filmów Fabularnych w Gdańsku, 1985 - nagroda za debiut reżyserski, najlepsze zdjęcia - Brązowe Lwy - Witold Adamek; Złota Kaczka 1985, przyznawana przez czasopismo „Film” za najlepszy film polski; Chicago, 2010 (Festiwal Filmu Polskiego w Ameryce) Nagroda Specjalna Przewodniczącego Komitetu Organizacyjnego Festiwalu „dla klasyka polskiego kina, filmu, którego uniwersalne wartości humanistyczne oraz wysoki poziom artystyczny stanowią o ponadczasowym wymiarze" .

[13] Recenzentka „Kina” nazywała ów dualizm połączeniem „bajkowości” i „,atmosfery realizmu w guście czeskiego kina lat sześćdziesiątych" i uznała je za słabość, wynikającą z niezdecydowania reżysera i wahania się pomiędzy jedną a drugą konwencją estetyczną - B. Umińska, Wczoraj jak dziś, dziś, jak wczoraj. Yesterday, „Kino”1986, nr 1, s. 15.

[14] Yesterday... Wywiad z Radosławem Piwowarskim...

[15] Ibidem.

[16] I. Kalinowska, Radosław Piwowarski, [w:] Autorzy kina polskiego, red. G. Stachówna, B. Zmudziński, t. 3, Kraków 2007. 
będącej w strukturze społecznej marginesem marginesu. Okazuje się, że przestrzeń prowincji ma również charakter autobiograficznego nawiązania $\mathrm{i}$ to nie tylko $\mathrm{z}$ powodu miejsca urodzenia czy wspomnień z wakacji u dziadka w Miechowie. Potwierdzenie znajdujemy w cytowanym już wywiadzie:

\begin{abstract}
A.B.: Świat prowincji. To z niego, poza nielicznymi wyjątkami, z których najlepiej znanym jest warszawiak Jan Serce, wywodzą się bohaterowie twoich filmów. Dlaczego? Sam dorastałeś przecież w Warszawie.

R.P.: Tak, ale w tamtych latach Grochów przypominał prowincjonalne miasteczko. $\mathrm{W}$ tej dzielnicy były jeszcze piaszczyste ulice. Jednak ludzie, którzy tam mieszkali - gołębiarze, murarze, rzemieślnicy - byli rodowitymi warszawiakami. Wśród takich ludzi wyrosłem: autentycznych, rubasznych, wyrazistych. Mój ojciec ich rzeźbił. Tworzyli klimat dobrego sąsiedztwa[17].
\end{abstract}

Dla Piwowarskiego warszawska Praga jego młodości to także prowincja, a w swoim debiucie reżyser przywraca do życia jej aurę, tworzoną przez ludzi i miejsca. Tym samym artysta utożsamia się z rzeszą widzów na całym świecie, którzy również pochodzą z prowincji i czują się z nią emocjonalnie związani, przez co kreuje uniwersalną wspólnotę pamięci.

Młodzież z PRL-owskiej prowincji, będąca zbiorowym bohaterem Yesterday, funkcjonuje jako mikrospołeczność zepchnięta na boczny tor małomiasteczkowego życia i pozbawiona praw. Stara się jednak wypracować własną tożsamość, usilnie zabiegając o autonomię, o namiastkę niezależności, o osobistą wolność. Synonimem wolności, a zarazem narzędziem walki o nią staje się muzyka rockowa, reprezentowana przez tytuł piosenki zespołu The Beatles, będącej jednocześnie wyrazem jawnego, odautorskiego sentymentalizmu. Yesterday to przecież „chwytająca za serce”, sentymentalna piosenka o utraconej miłości i żalu za tym, co się utraciło. Widzimy też inny znak rozpoznawczy Piwowarskiego - filmowe, sympatią darzone „dziwolągi” (freaks). Są nimi nie tylko czterej

[17] Yesterday... Wywiad $z$ Radosławem Piwowarskim... nastolatkowie, którzy postanawiają grać stygmatyzowaną muzykę ze "zgniłego Zachodu”, lecz także ciotka Ringa, grana przez Krystynę Feldman, która rozumie pasję młodych oraz ich tęsknotę za innym światem i wolnością, uosabianymi właśnie przez tę muzykę.

Piwowarskiemu udało się pokazać nie tylko „wolnościowy” charakter muzyki jako pasji, ale także jej funkcję inicjacyjną. Podobnie jak marzenie o życiu marynarza i podróżach w telewizyjnym filmie Córka albo syn, w Yesterday $\mathrm{z}$ trudem „łapana” na spiralnie zwinięty miedziany drut muzyka $\mathrm{z}$ Radia Luksemburg stawała się oknem na wolny świat. Piwowarski zatem pokazał rolę muzyki w inicjacji społecznej i świadomościowej, ale także w inicjacji osobowej, a nawet wprost seksualnej, ponieważ zawstydzona sobą para, słuchając tej właśnie stacji, otwiera się na kiełkującą, młodzieńczą namiętność. W tej nocnej scenie charakterystyczna cecha stylu Piwowarskiego, polegająca na łączeniu w spójną estetyczną całość realizmu i stylizacji, jest szczególnie widoczna. Stylizacja obrazu świata ekranowego i nasycanie go emocjami związanymi ze wspominaniem młodości: młodzieńczej przyjaźni, pierwszej miłości oraz erotycznej inicjacji są tu narracyjnymi narzędziami, służącymi malarskiemu przedstawieniu przeszłości wspominanej jako Dolina Dzieciństwa i Młodości, której specyfika polega między innymi na wspólistnieniu tych dwóch cech: zakorzenionego $\mathrm{w}$ racjonalizmie realizmu oraz wyrastającej z irracjonalności uczuć stylizacji: wizualnej (odkształcony obraz świata, szerokoobiektywowe deformacje) oraz narracyjnej (konwencja gatunkowa melodramatu, ukształtowanie postaci ekranowych jako freaków).

„Niewinny erotyzm” wraz z muzyką są tu synonimami wolności i narzędziami jej zdobywania w wielu wymiarach. Oba te motywy są charakterystyczne dla rytuałów inicjacyjnych, których doświadczają w swoim życiu miejscowi Beatlesi, a zwłaszcza Ringo. W wymiarze społecznym muzyka była narzędziem walki w konflikcie pokoleń, formą buntu wobec nadzoru dorosłych. Granie w miejscach publicznych tego, co się chce - zakazanej muzyki z wolnego 
świata - było sposobem odrzucania zewnętrznych ograniczeń, manifestowania niezależności i odrębnej grupowej tożsamości młodych. W wymiarze osobistym był to gest przyjęcia odpowiedzialności za własne życie, ze wszystkimi tego konsekwencjami. Zewnętrznym reprezentantem ograniczeń wolności w obu tych aspektach była szkoła, w tym nauczyciele. Reprezentatywny jest wątek apodyktycznego nauczyciela WF-u, Biegacza, którego interwencja zakłóca relacje między Anką i Ringiem oraz pośrednio prowadzi do próby samobójczej chłopaka.

„Niewinny erotyzm”, zbrukany przez ingerencję restrykcyjnego świata dorosłych, oraz motyw nieskrępowanej swobody i odkrywania sankcji, będących konsekwencją sięgania po „zakazany owoc” niezależności, są powtarzającymi się cechami stylistycznymi, charakterystycznymi dla kulturowo interpretowanej Doliny Dzieciństwa i Młodości.

Muzyka w Yesterday łączyła pasję, wolność i miłość, a w osobie ciotki tworzyła porozumienie między pokoleniami, zapowiadając późniejszą przemianę nauczycieli jako antagonistów młodych muzyków w osoby kanalizujące bunt przez jego instytucjonalne wchłonięcie. Przenikliwa jest pod tym względem jedna $\mathrm{z}$ końcowych scen, w której zamiast Ringa, przebywającego w szpitalu, w zespole zasiada nauczyciel WF-u, który dotąd prześladował grupę przyjaciół, utożsamiającą się z Beatlesami. Mamy tu wyraźne nawiązanie do tego, w jaki sposób władza wykorzystywała oddolne ruchy młodzieżowe, rodzące się na gruncie fascynacji muzyką Zachodu, w celu neutralizowania niezadowolenia społecznego, a czasem nawet zawłaszczania buntu i „przejmowania” dążeń wolnościowych. Nauczyciele, reprezentujący szkołę, będącą dla młodych ludzi organem władzy najbliższym ich życia, przejmują ów bunt, „szlifują jego kanty”, odbierają mu autentyczność, pozbywając się osób najbardziej niesubordynowanych i zajmując ich miejsce. Zatem w tym aspekcie jest to również film, który zawiera bardzo celne obserwacje o charakterze analizy społeczno-politycznej rzeczywistości PRL-u, pomimo deklaracji reżysera, że polityka go nie interesuje.
Jednak „polityka” czasów PRL-u „interesowała się" życiem zwykłych ludzi.

W warstwie kulturowego mitu finał filmu jest wyraźnym zamknięciem wejścia do Doliny Młodości. Kamera wycofuje się ze świata młodzieńczych wspomnień, płynnie przechodząc od świadomości młodego buntownika do świadomości rozczarowanego własnym życiem czterdziestolatka, który jest wciąż tą samą osobą. „Na połowie czasu” dochodzi do prawdziwej klęski w formie życiowego banału, jakim jest rozwód z niegdysiejszą ukochaną, która była synonimem tego, co najlepsze w Dolinie Młodości: piękna, wolności, entuzjazmu, wspólnoty przeżyć, lojalności, wspólnie przeżywanej radości, tajemnicy.

W Marcowych migdałach (1989) z kolei Piwowarski wykazał się umiejętnością zachowania balansu, łącząc cechy charakterystyczne dla pogodnej, a zarazem nostalgicznej opowieści o „kraju lat dziecinnych”[18] oraz celnych obserwacji polskiej rzeczywistości roku 1968 na przykładzie małej, lokalnej społeczności. W Epilogu epopei Mickiewicza znajdziemy wszystkie konstytutywne cechy Doliny Dzieciństwa i Młodości jako umitycznionego uniwersum. Jest to świat szczęśliwy, dobrze znany, idealizowany od strony estetycznej, a przede wszystkim bezpieczny. Toutes proportions gardées Piwowarski, podobnie jak Mickiewicz, wizualizuje świat bezpiecznej, polskiej prowincji, dającej poczucie zadomowienia i szczęścia oraz podobnie odwołuje się do zbiorowych, kulturowych mitów:

Ten kraj szczęśliwy, ubogi i ciasny,

Jak świat jest boży, tak on był nasz własny!

Jakże tam wszystko do nas należało!

Jak pomnim wszystko, co nas otaczało [...]

I tylko krajów tych obywatele

Jedni zostali wierni przyjaciele, jedni dotychczas sprzymierzeńcy pewni!

Bo któż tam mieszkał? - Matka, bracia, krewni!

Sąsiedzi dobrzy. Kogo z nich ubyło,

Jakże tam o nim często się mówiło[19].

[18] A. Mickiewicz, Epilog, [w:] idem, Pan Tadeusz, Warszawa 1964, s. 349.

[19] Ibidem [wyróżn. M.M.]. 
Dolinę Młodości zamieszkują przyjaciele, których „ubyło”, a Tomek, porte parole reżysera, od pierwszych ujęć pojawia się z aparatem fotograficznym, co sygnalizuje sposób utrwalania tego odchodzącego świata $\mathrm{w}$ formie materializującego się obrazu. Aparat $\mathrm{w}$ filmowym „tekście” reprezentuje kamerę, będącą z kolei narzędziem przetwarzania obrazów pamięci w obrazy ekranowe.

Reżyser w kolejnej kompaktowej opowieści zawarł obserwacje i emocje charakterystyczne dla „pierwszego kochania” i pierwszych erotycznych fascynacji oraz ze szczegółami nakreślił topografię prowincjonalnego miasteczka jako Doliny Dzieciństwa i Młodości. Tym razem jeszcze wzmocnił element realistyczny, choć wciąż mamy do czynienia $\mathrm{z}$ realizmem stylizowanym. Indywidualnie i grupowo przeżywane doświadczenie grozy, którego źródłem jest opresyjny system społeczno-polityczny, nieco tylko przysłonięty powierzchnią na poły „bezpiecznej prowincji”, w obiektywie reżysera zyskuje charakter świadectwa. W narracji tego filmu Piwowarski łączy w jednolity konglomerat nostalgiczność i realizm, będące charakterystycznymi cechami jego specyficznego stylu. Filmowy Lubin, wyjąwszy kontekst polityczny, mógłby być wszędzie i dlatego może być traktowany jako mityczna Dolina Dzieciństwa, wykreowana przez mechanizmy pamięci oraz wspominania. Jednocześnie jednak w pierwszej rozmowie, którą słyszymy z ekranu, profesor Olszyna w sposób egzaltowany podkreśla swoistość i wyjątkowość tego miejsca jako specyficznie polskiego, „naszego”. Natrętnie dopomina się od sceptycznego Tomka, by też się zachwycił i przyznał, że nigdzie nie ma takiego powietrza, takiego pejzażu itp. Cała następująca po tym filmowa opowieść wydaje się próbą nie tyle zachowania balansu między owym sceptycyzmem a bezkrytycznym, pełnym miłości zachwytem, ile odnalezienia trzeciej drogi, która łączyłaby te dwie sprzeczności.

Poczucie wyodrębnienia przestrzeni miasteczka $\mathrm{z}$ otaczającego świata, $\mathrm{w}$ tym $\mathrm{z}$ reszty Polski tamtego czasu, jest uzasadnione i topografią (podgórska dolina) i położeniem geo- graficzno-społeczno-kulturowym - prowincja, oddalona znacząco od stolicy oraz głównego nurtu życia społeczno-politycznego i kultury. W konsekwencji rodzinne miasto Tomka jawi się nie tylko jako bezpieczna kraina dzieciństwa, ale w miarę bezpieczne miejsce do życia w ponurych czasach sowieckiej dominacji w tej części świata. Zgodnie z powiedzeniem „nasza chata z kraja”, mieszkańców Lubina (w tym zwłaszcza młodzież) niewiele obchodzi to, co dzieje się gdzieś daleko w politycznym Centrum. Wszyscy zdają sobie sprawę, że do miasteczka „na końcu świata” niewiele dociera z zawirowań wielkiej polityki. Tu może być ona traktowana jak fikcja, która podlega karnawalizacji. Zarówno polityczna utopia w ówczesnej wersji pop (odgrywane w szkolnym teatrze przedstawienie o „Leśnym Władku” - prokomunistycznym partyzancie $\mathrm{z}$ okresu II wojny światowej), jak i realne działania na zlecenie władzy (manifestacja poparcia dla działań I sekretarza KC PZPR Władysława Gomułki przeciw tzw. Syjonistom) stają się pretekstem do zabawy, a nawet zgrywy.

Zarówno w scenerii, jak i w fabule oraz jej nostalgicznym ujęciu widać wyraźnie inspiracje autobiograficzne. Rodzinna Olszówka Piwowarskiego była tego typu miasteczkiem, a przyszły reżyser wychował się $\mathrm{w}$ podobnym środowisku - w rodzinie artystów, którzy reprezentowali bardzo stary wzorzec kulturowy ubogiego inteligenta, łączącego rozwiniętą autoświadomość z ekonomiczną mizerią.

Jednak - jak wynika $z$ filmowej narracji - i tam złowrogie wpływy polityczne docierają, nie tylko w postaci nakazów fasadowych działań propagandowych, takich jak artykuł w szkolnej gazetce czy udział szkoły w politycznej manifestacji dla poprawienia frekwencji. Groźna władza dosięga swoimi działaniami bezpośrednio bohaterów opowieści - żyjących dotąd w miarę bezpiecznie mieszkańców Doliny Dzieciństwa. Działania systemowe (nawet jeśli wykonywane przez miejscowych oficjeli bez zrozumienia i niechętnie) w postaci konkretnych decyzji i represji (nakaz opuszczenia kraju przez obywateli narodowości żydowskiej) 
oraz propagandowe (propagandowy przekaz medialny, manipulacje, intrygi) nie tylko prowadzą do dramatu wypędzenia - (przymusowej emigracji) sporej grupy mieszkańców miasteczka, ale także wywołują podejrzliwość, inspirują nieufność wśród przyjaciół.

Na końcu filmowej historii na peron wjeżdża pociąg z legendarnym - jak się wydawało - Leśnym Władkiem. Przybycie bohatera, „uśmierconego” podczas szkolnych akademii dla lepszego efektu dramaturgicznego, zamyka, a zarazem anihiluje niejako mityczne opowieści kreowane z pasji twórczej uczniów i nauczycieli oraz dla propagandowego efektu. Z tej wyraźnie mityzowanej opowieści, zamkniętej narracyjną ramą, wyłania się jednak realistyczna historia, symbolizowana przez drugi pociąg stojący na innym torze, poza oficjalno-propagandową wersją życia małomiasteczkowej społeczności, reprezentowanej przez szkołę i miejskie władze. Tym drugim pociągiem odjeżdżają mieszkańcy filmowego Lubina, których zupełnie realnie dotknęły konsekwencje ideologicznej utopii. Wyjeżdżają zaszczuci obywatele, których miejscowa władza określiła jako Żydów, więc persony non gratae w 1968 roku. Jest wśród nich jeden z dwóch głównych bohaterów filmu, pary nierozłącznych przyjaciół - Marcyś, utalentowany aktor szkolnego teatrzyku, odtwórca roli Leśnego Władka, który sam podczas manifestacji krzyczał „Syjoniści do Syjonu” z pełną świadomością absurdalności haseł, które kazano im wznosić.

Piwowarski, pozostając w lekkiej formule gatunkowej melodramatu oraz nostalgicznej opowieści o Dolinie Dzieciństwa, odtwarza i zarazem analizuje mechanizmy działania propagandy, od decyzyjnego centrum po najniższe szczeble. Szkoła w tym filmie (podobnie jak $\mathrm{w}$ innych tego reżysera) jest traktowana jako lokalna reprezentacja systemu polityczno-społecznej przemocy, uczestnicząca w propagandowej machinie, a że jest najbliżej młodych ludzi, więc za jej sprawą doświadczają oni działania systemu opresji. Na przykładzie szkoły widać wyraźnie efektywność mechanizmu współuczestniczenia poszczególnych jednostek w kreowaniu owego systemu. Jest on sprzężony z różnymi stopniami świadomości jego funkcjonowania, ponieważ jedni, jak dyrektorka szkoły, realizują nakazy z przekonaniem i wiarą, inni, jak profesor Olszyna - z przekonaniem o słuszności racji ideologicznych i ze świadomością fałszu samych działań, wreszcie młodzież z liceum, w tym główny bohater, Tomek, podporządkowuje się im, zachowując dystans wynikający z poczucia dysonansu poznawczego między oficjalnym przekazem a realnymi działaniami oraz ich skutkiem.

Na przykładzie młodzieży najlepiej widać cztery poziomy działania ideologicznej propagandy: kreowania obrazu rzeczywistości, oddziaływania owego obrazu rzeczywistości na świadomość osób poddawanych jego ideologicznym wpływom, świadomości owych mechanizmów oraz pragmatycznych konsekwencji całego systemu. Finałowa scena, gdy Marcyś na peronie żegna się z ich wspólną Doliną Dzieciństwa, doliną szczęśliwej, beztroskiej, mimo wszystko, teraźniejszości, która właśnie staje się przeszłością, skupia w sobie wszystkie cztery poziomy, akcentując jednak najmocniej ów ostatni - wpływ ideologicznej utopii na życie młodych ludzi i całej społeczności małego miasteczka. Jest ono w tym momencie reprezentacją wielu polskich miasteczek końca lat sześćdziesiątych, zwłaszcza w roku 1968, kiedy to nastąpiła kolejna w polskim życiu zbiorowym nienaturalna wyrwa, która zubożyła zarówno potencjał społeczny polskiego społeczeństwa, jak i dotknęła emocjonalnie wiele osób, stając się życiową traumą jednostek, grup przyjacielskich, rodzin, mikrospołeczności, a w końcu całej wspólnoty narodowo-obywatelskiej.

W Marcowych migdałach doskonale widać charakterystyczną dla stylu Piwowarskiego umiejętność łączenia realistycznego obrazu rzeczywistości przeszłej oraz jej mitotwórczego transformowania, za sprawą rozmaitych mechanizmów, przede wszystkim związanych ze wspominaniem, funkcjonującym w strukturze filmowej opowieści jako powrót do osobistej przeszłości. U tego reżysera wspominanie czasów młodości jest rodzajem „podroży sen- 


\section{8}

VARIA

tymentalnej", gdyż oznacza kreowanie powiązanych ze sobą sekwencji obrazów osobiście przeżywanej przeszłości. Tego rodzaju dyspozycja reżysera sprawia, że filmowy obraz jest realistyczny i analityczny, a zarazem nostalgiczny, a więc odkształcony poprzez uczuciowy ogląd podmiotu wspominającego, którym w wypadku Marcowych migdałów nie jest bohater ani wewnątrzfilmowy narrator, tylko reżyser jako zewnętrzny kreator filmowej opowieści. W ten sposób powstaje subiektywizowany obraz rzeczywistości przeszłej, lekko sentymentalnie zniekształcony, ale jednak jako całość wiarygodny, wiarygodnością nie tyle dokumentu, ile osobistego świadectwa i przenikliwego spojrzenia na przeszłość z perspektywy lat, które od tamtego czasu upłynęły. Widać wyraźnie, że odległość w czasie pozwoliła nabrać dystansu do tamtej rzeczywistości, do bohatera oraz jego najbliższego otoczenia $\mathrm{z}$ tamtych lat.

Filmowa opowieść Piwowarskiego łączy w sobie zlewające się w jedno trzy płaszczyzny odpowiadające trzem sposobom ukazywania przeszłości i postrzegania jej przez narratora. Po pierwsze, jest to zanurzenie się w przeszłym świecie, niejako „powrót do przeszłości” w znaczeniu przeniesienia w czasie, po drugie, jest to sentymentalne, pełne ciepłych uczuć wspominanie swojej młodości z naciskiem na ludzi, którzy ją współtworzyli, po trzecie, jest to celowe, metodyczne użycie elementów kreujących te dwie pierwsze płaszczyzny w taki sposób, by obnażyć w analitycznym ujęciu mechanizmy rządzące tamtym światem. Dzięki specyficznej strukturze filmowej narracji obraz rzeczywistości w obiektywie Piwowarskiego jest jednocześnie zobiektywizowany, analityczny i osobisty, realistyczny i nostalgiczny. Realizm pamięci w Marcowych migdałach polega na tym, że oprócz częstej u tego reżysera przenikliwości i wrażliwości społecznej, jak również kulturowo-społecznej, w filmie tym ujawnia się zmysł analityka zjawisk o charakterze polityczno-ideologicznym.

W obrazie miasteczka na ekranie, pomimo dramatyzmu niektórych zdarzeń oraz intensywności ich przeżywania przez młodych ludzi, dominuje poczucie bezpieczeństwa, charakterystyczne dla motywu Doliny Dzieciństwa. Odczucie to wynika z zamkniętego charakteru czasu wspomnień jako czasu przeszłego dokonanego, w którym niczego już nie można zmienić, ale który, jakkolwiek nie byłby straszny czy naznaczony własnymi błędami, a nawet podłościami, jest także czasem w jakiś sposób dobrym, bo osnutym nostalgią. Okres młodzieńczej wspólnoty, tworzonej z innymi młodymi, z przyjaciółmi, których już nie ma w życiu narratora lub których nie ma takich, jakimi byli wówczas, kiedy jeszcze wszyscy byli razem, gdy wszystko jeszcze było przed nimi, postrzega się z pewną łagodnością, „W miękkim świetle”, jak to określił Piwowarski w cytowanej wyżej wypowiedzi.

Historia klasy maturalnej z podgórskiego miasteczka opowiedziana została w taki właśnie sposób - sentymentalnie i nostalgicznie, bo przyjaciele odjechali na zawsze... Symptomatyczny jest finał, gdy Tomek początkowo chowa się za węgłem, jakby nie chciał Marcysia pożegnać, ten zaś do końca rozgląda się, czekając na niego. Wreszcie, gdy pociąg rusza, Tomek biegnie za nim, starając się przekazać przyjacielowi najcenniejszą pamiątkę - szablę po dziadku-legioniście, który dożywał swoich dni w skrajnej biedzie. Gdy wydaje się, że Tomek już nie dogoni pociągu, w ostatniej chwili Marcyś łapie za klingę i zostaje z szablą Tomka w ręku, gdy tymczasem Tomkowi pozostaje pochwa. Tym samym w symbolicznej scenie pokazał reżyser wspólnotę tradycji Rzeczpospolitej, na którą składa się przeszłość i kultura nie tylko „Obojga Narodów”, jak było w czasach jagiellońskich i nie tylko polskiej i żydowskiej kultury, ale wielu narodów i kultur, z trzonem sarmacko-szlacheckiej tradycji, z którą wszyscy współtworzący narodową wspólnotę się utożsamiają, bez względu na indywidualne korzenie etniczne, religijne czy kulturowe. Reżyser pokazuje w tej scenie zarazem emocjonalny związek młodych i starszych Polaków z tradycją, rozumianą jako przeszłość w nas, żywą i żyjącą, jak i jej zobiektywizowany charakter, wyrażający się w artefaktach kulturowych, łączących w sobie dorobek materialny 
oraz kulturę symboliczną - materialne ślady wspólnej przeszłości, przekazywane z pokolenia na pokolenie, oraz wartości i pamięć, które są przez nie symbolizowane. W ten sposób Tomek włącza swojego przyjaciela Marcysia, uznanego przez władzę za obcego, do łańcucha tradycji zbudowanej na dawnym zaangażowaniu, czynach (wojskowych i nie tylko) oraz uczuciach związanych $\mathrm{z}$ pamięcią rodzinną i osobistą (wspomnienia dziadka o czynach legionowych), jak również z pamięcią i symboliką wspólnotową (tradycja rycerska i niepodległościowa, symbolizowana przez szablę). Łańcuch, tworzony przez międzypokoleniową transmisję, dokonującą się w pierwszym etapie wewnątrz rodzin, zostaje poszerzony o synchroniczny, horyzontalny przekaz, możliwy, dzięki autentycznym więzom między młodymi mężczyznami, dzięki „braterstwu duchowemu”. Tradycja narodowa dalej jest budowana na emocjonalnym zaangażowaniu, którego reprezentacją w opowieści Piwowarskiego staje się przyjaźń młodych ludzi oparta na codziennych kontaktach, zainteresowaniach, wartościach oraz ich wspólnotowym przeżywaniu. Jednak kośćcem tradycji narodowej jako cennego depozytu wartości wspólnych, będących dorobkiem[20] zbiorowości, pozostaje przeszłość wbudowana w osobową tożsamość jednostki, tworzącej cząstkę społeczności lokalnej i narodowej jako jej podstawa.

Z Doliny Dzieciństwa wyjeżdża Marcyś, niosąc ze sobą w świat jako emigrant z przymusu wszystko to, co symbolizuje szabla polskiego legionisty-Piłsudczyka. Tomek z tym samym depozytem symbolicznych wartości pozostaje. Przywołanie epopei narodowej na początku nie jest nadużyciem i nie jest przypadkiem, ponieważ Piwowarski w tym filmie zupełnie jawnie do narodowej tradycji się odwołuje. Czas budowania osobowej tożsamości obu bohaterów się zakończył w tym momencie, a dokonał się właśnie tu, w podgórskim miasteczku, na polskiej biednej prowincji, w Dolinie Dzieciństwa: pięknej, smutnej i strasznej, bo pod ciemną chmurą politycznej opresji, a jednak wypełnionej śmiechem młodych ludzi, muzyką i erotyczną aurą. Czas bezpiecznego, choć nie-beztroskiego dojrzewania właśnie minął.

Najczęściej nagradzanym filmem Piwowarskiego na świecie, oprócz Yesterday, jest Pociąg do Hollywood (1987), w części zapewne ze względu na siłę mitotwórczą i manifestację autorskiego stylu reżysera. Oglądając ten film, odnosi się wrażenie, że był realizowany z uśmiechem na ustach. Doliną Dzieciństwa jest tu kino rozumiane jako kraina marzeń (Dreamland) i to spełnionych marzeń. Tytułowy pociąg - kwintesencja PRL-owskiej brzydoty i marności ludzkiej egzystencji w najmizerniejszych warunkach materialnych, wiezie, mimo wszystko, do prawdziwego Hollywood parę sympatycznych bohaterów, którzy mają odwagę marzyć o niemożliwym. Kino zatem, z halą zdjęciową jako miejscem akcji finałowej sekwencji, jest nowym ucieleśnieniem Doliny Dzieciństwa. Jest to Dolina Dzieciństwa odzyskana za sprawą marzeń i wciąż odzyskiwana dzięki wyobraźni artystów-filmowców, takich, jakim może stać się Piotruś i takich, jak jego Gwiazda - Mariola Wafelek. Śliczna barmanka może stać się prawdziwą diwą dzięki magii ekranu oraz za sprawą filmowych sztuczek, ale przede wszystkim dzięki własnemu urokowi i wewnętrznemu światłu. Może jako Merlin błyszczeć na ekranie, czyniąc z filmowego świata obraz Ziemi Obiecanej i Raju Odzyskanego zarazem. Chociaż w hali zdjęciowej Dolina Marzeń jest wykreowana w sposób sztuczny, staje się jednak wiarygodną rekonstrukcją marzeń. Re-konstrukcja musi być trochę sztuczna $\mathrm{z}$ definicji, a stworzona została $z$ dwóch niekompatybilnych na pozór elementów: techniki oraz pasji twórczej i wyobraźni reżysera-artysty. Jednak przeżycia wywołane wykreowanym na ekranie obrazem będą równie autentyczne i intensywne, jak emocje

[20] Odwołuję się tutaj do klasycznej definicji kultury Stefana Czarnowskiego: „Kultura jest dobrem zbiorowym i zbiorowym dorobkiem, owocem twórczego i przetwórczego wysiłku niezliczonych pokoleń". S. Czarnowski, Dzieła, oprac. N. Assorodobraj, S. Ossowski, Warszawa 1956, t. 1, s. 13. 
związane z dzieciństwem, które przeminęło i z marzeniami, które czasem stają się siłą napędową życiowych działań.

Obie główne postacie są typowymi freakami. Piotruś (Piotr Siwkiewicz - rola napisana specjalnie dla tego aktora), marzący o karierze filmowca, łączy w sobie skrajną kulturową sprzeczność, dwa typy, które powinny się wykluczać. Jest uroczym fajtłapą i poczciwcem, a jednocześnie easy riderem, człowiekiem pozostającym poza głównym nurtem, starającym się zachować własną odrębną tożsamość, mającym odwagę podążać za niemożliwymi do spełnienia marzeniami[21]. Dodajmy, że owa niemożność przemiany przyziemnego świata $\mathrm{w}$ świat młodzieńczych marzeń jest związana z faktem, iż codzienność, w której marzyciele muszą funkcjonować, jest rzeczywistością ponurego PRL-u.

Mariola Wafelek - „Merlin” (Katarzyna Figura) nosi znaczące nazwisko, bo jest tak śliczna, że chciałoby się ją schrupać. Jednocześnie w tej „śliczności” jest przerysowana i kiczowata. Wyraźnie wpisuje się Piwowarski w stylistyce postaci w tradycję humoru Aleksandra Fredry, a filmowo - w stylistykę niektórych postaci Felliniego, którego Piwowarski przywołuje jako swoją inspirację, obok szkoły czeskiej[22]. Dodatkowo, źródłem komizmu jest kontrast między urokiem postaci, urodą marzeń, sięganiem po nieosiągalne oraz świadomym nawiązaniem do estetyki tradycyjnego kina hollywoodzkiego a turpizmem otoczenia, w którym bohaterowie egzystują. Poczucie dysonansu wzmacnia wyrażane expressis verbis podobieństwo Marioli

[21] Pierwowzorem tego typu bohatera był wykreowany w okresie kina niemego przez Charlesa Chaplina Charlie.

[22] Yesterday... Wywiad z Radosławem Piwowarskim...

[23] Pisałam o tym zjawisku szerzej w latach dziewięćdziesiątych: M. Marczak, Boże dziwolagi. Rola humoru, groteski i karykatury w kształtowaniu chrześcijańskiej perspektywy filmów, [w:] Świat w zabawie, zabawa światem. Ludyczne koneksje literatury, red. D. Ossowska, A. Rzymska, Olsztyn 2001, s. 135-146. do gwiazdy kina o największej sile mitotwórczej w popkulturze (Marilyn Monroe) zestawione z przyziemnością otoczenia i jej codziennych zajęć. Znaczące stylistycznie jest wspólne kadrowanie młodziutkiej Merlin i nieatrakcyjnej kolejarki (Krystyna Feldman), przy czym zestawienie to nie ośmiesza starej, pomarszczonej kobiety. Obie wyrosły z brzydoty otoczenia i obie wyrastają ponad stereotypowość obrazu PRL-u, ponieważ się z niego wyróżniają. Piwowarski ma szczególny dar, który wyraźnie dzieli z Fellinim, polegający na posługiwaniu się groteską w kształtowaniu obrazu postaci na ekranie, a jednocześnie jawnie manifestowanej życzliwości dla tak przedstawionych bohaterów[23]. Można powiedzieć, że reżyser wynajduje w rzeczywistości ciekawe typy, które na ekranie dodatkowo deformuje, żeby pewne cechy uwydatnić, ale nie tworzy karykatury. Potrafi utrzymać ten delikatny balans i nigdy nie przekracza granicy między humorem postaci a jej ośmieszeniem. W filmach tego reżysera z miłością pokazane zostały nasze polskie, poczciwe „dziwolągi” - outsiderzy z biednej prowincji - naprawdę Inni: wyjątkowi ze względu na marzenia, wyobraźnię, pragnienia, aspiracje, ale też dlatego, że są słabsi, delikatniejsi, bardziej wrażliwi. Czasem są słabsi fizycznie, ułomni i dlatego zmarginalizowani. Innym razem okazują się słabsi społecznie lub zostali zmarginalizowani systemowo ze względu na przynależność do grupy środowiskowej, jak dzieci (Synek z Kochanków mojej mamy) czy młodzież (Yesterday, Marcowe migdały) lub ludzie starzy bądź starzejący się (bohaterka Feldman z Pociągu do Hollywood, dziadek - bohater - legionista Piłsudskiego z Marcowych migdałów). Bywają biedni lub/i mieszkają na prowincji (bohaterowie Miasteczka). Niekiedy po prostu nie pasują do otoczenia, choćby ze względu na kontrast między „szlacheckością” wyjątkowej urody (Mariolka) a otoczeniem i funkcją bufetowej w pociągowym przedziale barowym. Wars w PRL-u pod koniec trasy był kwintesencją materialnej i społecznej mizerii, tego, co odrażające, w czym wszyscy demokratycznie i egalitarnie tkwili, jeśli chcieli lub 
musieli przejechać z Przemyśla do Szczecina, z Ełku do Zakopanego lub z Cieszyna do Olsztyna.

Piwowarski nie upomina się o nich, robiąc kino zaangażowane, to nie jest jego estetyka ani jego wrażliwość. Artysta ich upodmiotawia oraz oferuje ucieczkę w świat kina jako krainę spełnionych marzeń. Dowartościowując swoich bohaterów oraz czyniąc ich w pełni autonomicznymi podmiotami opowieści, podkreśla ich wewnętrzne piękno. Wpisuje się tym samym w tradycję Felliniego i - podobnie jak w przypadku bohaterów włoskiego mistrza - polskie freaki Piwowarskiego nie są świętymi w sensie etycznej doskonałości. Reżyser pokazuje swoich bohaterów jako ludzi interesujących, którzy mają swój wewnętrzny świat, swoją historię i dlatego warci są tego, by ich dostrzec i wydobyć z szaro-burego tła na światło dzienne. W końcu widzowie dostrzegają jakieś światełko, które w sobie noszą. Szczególnie reprezentatywna dla tego elementu poetyki Piwowarskiego jest postać starej malarki i fantastki - Mimi (Danuta Szaflarska) z Królowej chmur (2003), odcinka telewizyjnego cyklu Święta polskie, będącego fantazją na temat Dnia Matki.

Po latach realizowania prawie wyłącznie seriali telewizyjnych reżyser znów pokazuje tu swoją najlepszą formę, opowiadając ciepłą historię na granicy sentymentalizmu, gdzie realizm pięknie wystylizowany sprawia, że uczucia manifestują się z całą mocą a elementarne wartości, jak w baśni, ostają się zwycięsko w finale. Nie wiadomo, czy mylenie rzeczywistości z marzeniami jest fantazjowaniem starej malarki chmur, czy skutkiem starczego uwiądu, czy świadomą decyzją, by nie godzić się z rzeczywistością, ale zawalczyć o własną podmiotowość, żeby spektakularnie zaistnieć jako artystka życia. Dziecięcy rys osobowości artysty jest w całym tym filmie, szczególnie zaś w postaci starej artystki, bardzo dobrze widoczny. Narrację napędza niezgoda na rzeczywistość, jadącej do domu starców wiekowej malarki, jej nieustanne pragnienie, aby ubarwiać i upiększać to, co w życiu niepiękne. Balansowanie na granicy realności i marzenia, które są udziałem Mimi, wytwarza tego rodzaju presję na rzeczywistość, że ona w końcu zostaje odrobinę skorygowana, zgodnie z kształtem marzeń. Nie wiadomo, czy stara malarka traci świadomość tego, w jakim świecie żyje, czy tylko sprytnie stylizuje się na wariatkę, która nie uznaje rzeczywistości, jaka jej nie odpowiada. W końcu musi się z nią pogodzić i pozostać w domu starców, ale dzięki życiu pełnią, dzięki swojej barwnej osobowości, marzeniom i artystycznej kreacji przełamuje egoizm młodego towarzysza podróży, który przyjmuje w finale niechcianą funkcję przybranego syna. Bohaterce, stworzonej przez reżysera, udaje się niejako skasować wyrok samotności, coraz powszechniejszy w tej grupie społecznie wykluczonych, jaką są ludzie starzy. To ich właśnie w tym filmie Piwowarski upodmiotawia, co uznać trzeba za postawę z gruntu chrześcijańską. Technika przedstawieniowa jest podobna jak u Felliniego, chociaż styl różny. Piwowarski również nie upiększa fizycznie ani psychologicznie tych postaci, nie idealizuje ich, tylko je uwyraźnia, co daje czasem efekt przesady, ale nigdy karykatury. Podobnie jak włoski mistrz Piwowarski kocha swoich bohaterów, nie wyśmiewa, ich obraz jest jednocześnie realistyczny i stylizowany - podobnie jak obraz rzeczywistości, w której funkcjonują.

Prozaiczna podróż do domu opieki, postrzeganego przez potencjalną pensjonariuszkę jako ponura umieralnia dla samotnych starych ludzi, jest dla żywotnej artystki pełnej fantazji z pewnością degradacją. Za sprawą jednak jej aktywnej postawy i wyobraźni staje się przygodą życia, otwarciem wrót do Doliny Młodości. $\mathrm{W}$ tej wersji nie jest ona uniwersum zamkniętym w czasie przeszłym dokonanym, do której dostęp możliwy jest za sprawa wspomnień. Dzięki wyobraźni malarki oraz jej psychicznej niejednoznaczności, realna, teraźniejsza rzeczywistość miesza się z jej subiektywnym obrazem, stworzonym przez konglomerat marzeń, wspomnień, wyobrażeń i artystycznej kreacji.

Nawiązaniem do stylistyki Doliny Młodości są estetyzujące zdjęcia, w których Mimi jest filmowana na początku we wnętrzu wypełnionego obrazami i antykami domu, a następnie 
w urokliwych wiejskich lub leśnych plenerach, w czasie jazdy samochodem lub krótkich przerw w podróży. Dzięki obrazom pełnym światła, nieraz filmowanym w zwolnionym tempie i niezwykłym punktom widzenia stara kobieta jest pokazana jako osoba pełna uroku, energii, wewnętrznego światła. Widz widzi i czuje, że ona sama jest wyjątkowa, ale także że przebywa w jakiejś innej rzeczywistości, dla której realny świat, w którym funkcjonuje jej towarzysz, jest materialną bazą. Ona zaś przebywa w quasi-rajskim świecie, który jest nie tylko piękny urodą naturalnej polskiej wsi, dostrzegalną dla wszystkich, ale przede wszystkim jest szczęściodajny.

Styl Piwowarskiego jest złożony i, mimo pozorów lekkości i rozwichrzenia, precyzyjny, a nawet kunsztowny. Jego podstawową składową jest dokładna, skrupulatna nieraz obserwacja, wydobywająca z rzeczywistości oraz z postaci cechy istotne, które niejednokrotnie zostały ukształtowane pod wpływem otoczenia społecznego i politycznego. Reżyser szkicuje ekranowy obraz tej rzeczywistości, wydobywając prawdę o niej, ale efekt nie przypomina reprodukcji, lecz raczej stylizowany obrazek, na którym pewne realnie istniejące cechy, dostrzeżone przez autora, zostały uwydatnione, ale jednocześnie w wizualnym kształcie dzieła artysta ujawnia swój emocjonalny stosunek względem portretowanych postaci oraz utrwalonych elementów świata przedstawionego. Realizm Piwowarskiego jest realizmem pamięci, która tworzone przez artystę obrazy przeszłości co prawda stylizuje, nadając im emocjonalną jakość, ale zrazem dokumentuje sposób przeżywania przeszłości oraz jej zapamiętywania. Emocjonalność artystycznego ujęcia wynika z faktu, iż zwykle obrazowana jest przeszłość przeżyta przez bohatera, narratora lub tylko filmowca. Zyskuje ona kształt jakiejś wymyślonej historii, w której zachowano znaczące cechy rzeczywistości realnej, a czasem także realnych osób jako pierwowzoru. Rezultat, jak

[24] Yesterday... Wywiad z Radosławem Piwowarskim...

[25] Ibidem. to zwykle z twórczością artystyczną bywa, jest kompilacją prawdziwych doświadczeń i twórczej kreacji. Jest też konsekwencją podwójnej artystycznej fascynacji Autora, który przyznaje się do inspiracji zarówno czeską nową falą, jak i filmami Federica Felliniego: „Forma mojego kina kształtowała się zarazem pod wpływem bliskiego życiu małego realizmu Czechów, jak i nieskrępowanej wyobraźni artystycznej twórcy 8 i pól'[24] - wyznaje reżyser.

Cała ta technika jest jednak jak mechanizm lokomotywy, którego nie musimy być świadomi, a najczęściej wcale nie chcemy go znać. Ważne, że narracje Piwowarskiego są taką właśnie metaforyczną lokomotywą, zabierającą nas, widzów, w nostalgiczną podróż do jego Doliny Dzieciństwa i Młodości, zaskakująco często okazującej się także miejscem zadomowionym dla widzów, ponieważ obrazy z przeszłości artysty przypominają te, które mogliby zapamiętać inni świadkowie tamtych czasów, a więc także jego widzowie. Przenoszenie własnych doświadczeń w sferę mitu uniwersalizuje przekaz zawarty w narracjach Piwowarskiego na tyle, że stają się one swojskie nawet dla widzów w odległych miejscach świata, a polska prowincja staje się uniwersalną lokalnością, Doliną umiejscowioną „wszędzie”, w „krainie marzeń lub wspomnień", co potwierdza reżyser wspominając swoje spotkania $\mathrm{z}$ widzami:

\footnotetext{
Myślę, że istnieje coś takiego jak tajemnica prowincji. Większość ludzi na świecie pochodzi z prowincji. Prawie każdy z nas mieszkał kiedyś w jakimś miasteczku, miał marzenia i gitarę, słuchał ulubionego zespołu. Chyba stąd wziął się międzynarodowy sukces filmu Yesterday, który pokazywałem w dziesiątkach przeróżnych zakątków globu. Po projekcji zawsze podchodzili widzowie, mówiąc: „To film o mnie! Skąd pan zna moją historię?”[25].
}

Uczucia, którymi Piwowarski nasyca filmowe obrazy, są wspólne artyście oraz odbiorcom, zwłaszcza jeśli ci ostatni poddadzą się magii kina $\mathrm{z}$ dziecięcą lub quasi-dziecięcą spontanicznością, podobnie jak czyni to sam reżyser. 


\section{B I B L I O G R A F I A}

Caughie J., Half way to paradise, „Sight and Sound” 1992, 2/1, s. $11-13$

Czarnowski S., Dzieła, oprac. N. Assorodobraj, S. Ossowski. Warszawa 1956

Dabert D., Ostalgia i bezpowrotność w środkowoeuropejskim kinie przełomu, „Porównania” 2012, 11, s. 139-155

Kalinowska I., Radosław Piwowarski, [w:] Autorzy kina polskiego, red. G. Stachówna, B. Zmudziński, t. 3, Kraków 2007

Kowalski P., Odyseje nasze byle jakie. Droga, przestrzeń i podróżowanie $w$ kulturze współczesnej, Wrocław 2002

Lubelski T., Poetyka powieści i filmów Tadeusza Konwickiego. Wrocław 1984

Marczak M., Boże dziwolagi. Rola humoru, groteski i karykatury w kształtowaniu chrześcijańskiej perspektywy filmów, [w:] Świat w zabawie, zabawa światem. Ludyczne koneksje literatury, red. D. Ossowska, A. Rzymska, Olsztyn 2001, s. 135-146

Mickiewicz A., Epilog, [w:] A. Mickiewicz, Pan Tadeusz, Warszawa 1964

Piwowarski R., Sceny rozbierane, Warszawa 2016

Radstone S., Kino/pamięć/historia, [w:] Film i historia. Antologia, red. I. Kurz, Warszawa 2008, s. 337-358
Umińska B., Wczoraj jak dziś, dziś, jak wczoraj. Yesterday, „Kino” 1986, 1, s. 12-15

Voisine-Jechova H., Podróż jako doświadczenie, marzenie oraz poszukiwanie sensu egzystencji w prozie 1760 1820, [w:] Dziedzictwo Odyseusza: podróż, obcość i tożsamość, identyfikacja, przestrzeń, red. M. Cieśla-Korytowska, O. Płaszczewska, Kraków 2007

Wobec przeszłości: pamięć przeszłości jako element kultury wspótczesnej, red. A. Szpociński., Warszawa 2005

Zygmunt S., Czas wszystko zmienia, „Kino” 1995, 12, s. $4-5$

\section{W Y W I A D Y}

Co zrobić z wiśniowym sadem - Radosław Piwowarski, rozm. przeprowadził Jacek Cieślak, „Rzeczpospolita" 1998, 222, s. 23

Małe historie, przez które widać większe - Radosław Piwowarski, rozm. przeprowadził Michał Burszta, „Kino” 2009, 12/43, s. 54-55

Yesterday... Wywiad $z$ Radosławem Piwowarskim. Z Radosławem Piwowarskim rozmawia Andrzej Bukowiecki, „Magazyn Filmowy SFP”, 2014, 36, <https://www.sfp.org.pl/baza_wiedzy,311,20236, 1,1,Yestarday-Wywiad-z-Radoslawem-Piwowarskim.html>, dostęp: 17.08.2020 